\title{
MARIA CURIE-SKŁODOWSKA UNIVERSITY
}

\section{FACULTY OF PEDAGOGY AND PSYCHOLOGY}

\section{LUBELSKI ROCZNIK PEDAGOGICZNY}

VOL. 37, NR 3 (2018) 


\section{SPIS TREŚCI}

WSTĘP $\ldots \ldots \ldots \ldots \ldots \ldots \ldots \ldots \ldots \ldots \ldots \ldots \ldots \ldots$

A neta R. Borkowska, Piotr Francuz: Wykorzystywanie instytucjonalnych i innych form terapii przez uczniów z dysortografią . . . . . . . . . . . . . . . . . .

Monika Wypych: Postawy wobec trudności w uczeniu się i zespołu nadpobudliwości psychoruchowej z deficytem uwagi uczniów szkół zawodowycho zróżnicowanej pozycji socjometrycznej . . . . . . . .

Izabella Kucharczyk: Rozumowanie przez analogie semantyczne w kategorii przyczyna - skutek w grupie uczniów niewidomych . . . .

Maria Olszak-Winia rska: Problematyka jakości życia niepełnosprawnych w wybranych krajach europejskich (Niemczech, Norwegii i Polsce) w kontekście uregulowań prawnych . . . . . . . . .

Janusz Kirenko, Ewa Sienkiewicz, Jolanta Szymańska, A nna Malm: Socjodemograficzne uwarunkowania sposobów radzenia sobie w sytuacjach trudnych przez personel pielęgniarski . . .

Joanna Barbara Hoffmann-Aulich, Monika Sylwia

La to - P awłowska: Oczekiwania pielęgniarek dotyczące formy zwracania się do nich pacjentów . . . . . . . . . . .

Marek Cendrowski: Społeczeństwo bezpieczeństwa jako konsekwencje życia w płynnych czasach . . . . . . . . . . . . . . .

Łukasz Tomczyk: FOMO (Fear of Missing out) - wyzwanie

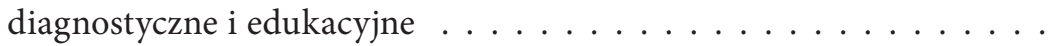


Małgorzata Chojak: Neuropedagogika i edukacja alternatywna w oświacie XXI wieku . . . . . . . . . . . . . . .

Mariusz Korczyński: Edukacyjne uwarunkowania kompetencji międzykulturowych Polaków na emigracji . . . . . . . . . .

Ilona Szostak-Jośko: Wartości „mieć”, „być” wśród uczniów szkół ponadgimnazjalnych ..................

A nna Boguszewska: O książce obrazkowej i jej wykorzystaniu dla dzieci przedszkolnych . . . . . . . . . . . . .

Michał Stolarczyk: Wychowanie państwowe w Drugiej

Rzeczypospolitej w świetle programów szkolnych (po wprowadzeniu reformy oświatowej z 1932 roku) . . . . . . . . . . . . . . 215

Ganna Tovkanets: Moral values in pedagogical activity . . . . . . 237

Leonid Orshanskyi: Orientation of future teachers towards humanistic

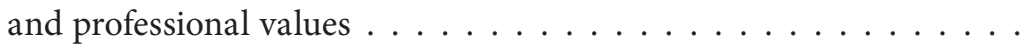

Liliya Morska: Educational values: current views and perspectives for modern school . . . . . . . . . . . . . . . . . . . .

Olesia Smolinska, Khrystyna Dzyubynska: Identification processes in cultural and educational space of the university as a source of the nascence of educational values . . . . . . . . .

A nna Fedorovych: Axiological dimensions of preschool teacher training in Ukraine . . . . . . . . . . . . . . . . .

Larysa Zdanevych, Kateryna Krutii: The "talking walls" technique and timely transformation of educational space of preschool educational institution $\ldots \ldots \ldots \ldots$ 